\title{
多変量データの解析における 直交関数の利用について
}

橋口涉子

農業技術研究所

要 旨 $n$ 人のパネルがゃ個の対象について食味を採点したデータをると に，そのp個のおの拉のに総合得点を与え，さらにそれの成分含量に対す る回帰式を導くことが目的である.このような多変量データに対し，考兄 られる $2 ， 3 の$ 手法の適用事例を示した．解析手法は主成分分析と直交多 項式の組み合わせであるが，それの組み合わせ方について若干の提案をし た．つまり，多変量データに対する值交関数の利用法についての提起とる いえる. そのひとつは, 積和行列の対角要素の和を直交多項式の回㷌平方 和に分割し，パネル全体のもつ総回帰項を把掘して若下の知見を得た。 らひとつは，回帰項を最大沉する主成分の導出であり，この導出は一般の 説明変数のデータでも可能であるが，なおそれに，説明变数を直交多項式 におきかえられる利点を付したるのである．さらに，積和行列を要因別に 分解して主成分を抽出し，採点の棈造を把握した．これら各手法の概要, および適用結果に沿って手法ならびにデータへの考察を記した。

\section{はじめに}

ある成分含量のちがいにより， $p$ 種類に分類された食品について，n人のパ ネルが与兄な順序によって採点を行ったデータがある. それをもとにして，成 分含量と食味との関係を把握しょうとするのが目的である。そのため，先ず 種頪の対象それぞれに，n人の採点に共通する“食味の得点”を与える必要が あると考无た，その理由は，1種類に対し $n$ 個のデータを，単なるくり返しの 如く同等に扱うにはバラッキが多寸ぎるからである。事実，単にパラッキとい 万以上に，採点基準のちがい，喍好の特異性などが混在したデータであると思 われた。この， $n$ 人に共通する “食味の得点”のことを, 以後「総合得点」と と呼ぶことにする. 
したがって，解析の目的としては，総合得点を求めること，成分含量に対する総合得点の回帰式を把握するこ と，のふたつ，といらことができる，こ礼らに対し，接近方法はさまざねであ万らが，ここでは $p$ 種類の対象に ついての糖，酸含量に関する多变量データを直交多項式が利用できるるのとして取り扱うことにより，その目的 に応劣ようとしたものである，用いた手法汇関しては，適用結果に対する実際的な検討る必要であるが，この小 論においては，手法について述べることに力点をおく。

\section{2. 具体的なデータ}

データは, 静岡県柑楅試験場の鈴木・石田（1976）による.温州ミカンについて 3 段階の糖と 4 段階の酸との 各含量の組み合わせにより，表1のように分類された。それぞれの種類に属するミカンの食咮について，20人の

表 1. 各成分含量とミカンの区分番号

\begin{tabular}{|r|r|r|r|r|}
\hline 酸\% & 0.75 & 0.95 & 1.15 & 1.35 \\
\hline 9.5 & 1 & 2 & 3 & 4 \\
10.8 & 5 & 6 & 7 & 8 \\
12.1 & 9 & 10 & 11 & 12 \\
\hline
\end{tabular}

パネルが 7 段階の䇢囲内で序数により採点した. ただし，実際に用いられた序数の範囲は，パネルにより不統一 であって必ずしも7段階の序数全部が用いられているわけではない。また，同じパネルルよる繰り返しはない。

用いられた序数の範围が不統一であるので，パネルごとに平均ゼロ，分散は一定になるようにデータを修正し た．以後，「データ行列」あるいは「六ルの採点」とは，原データでなく，この修正されたデータをさす。

先に还べたように，データ解析の最初の目的は，n人の共通性をできるたけ反映させた，総合得点を求めるこ とである. まず, 各パネルの採点の方向がどの程度一致しているかについて, 表 2 のパネル間皘和行列の各要素 から把握できる. 他の19人のパネルとの間の相関俰数のうち，半数近く負の值がみられるパネルが， $y_{1}, y_{2}$ 拉 び $y_{10}$ と，3 人認められる。これら 3 パネルを，特殊な赀好をもつものとして，分離することも考えられる。し

表 2. 平方和積和行列

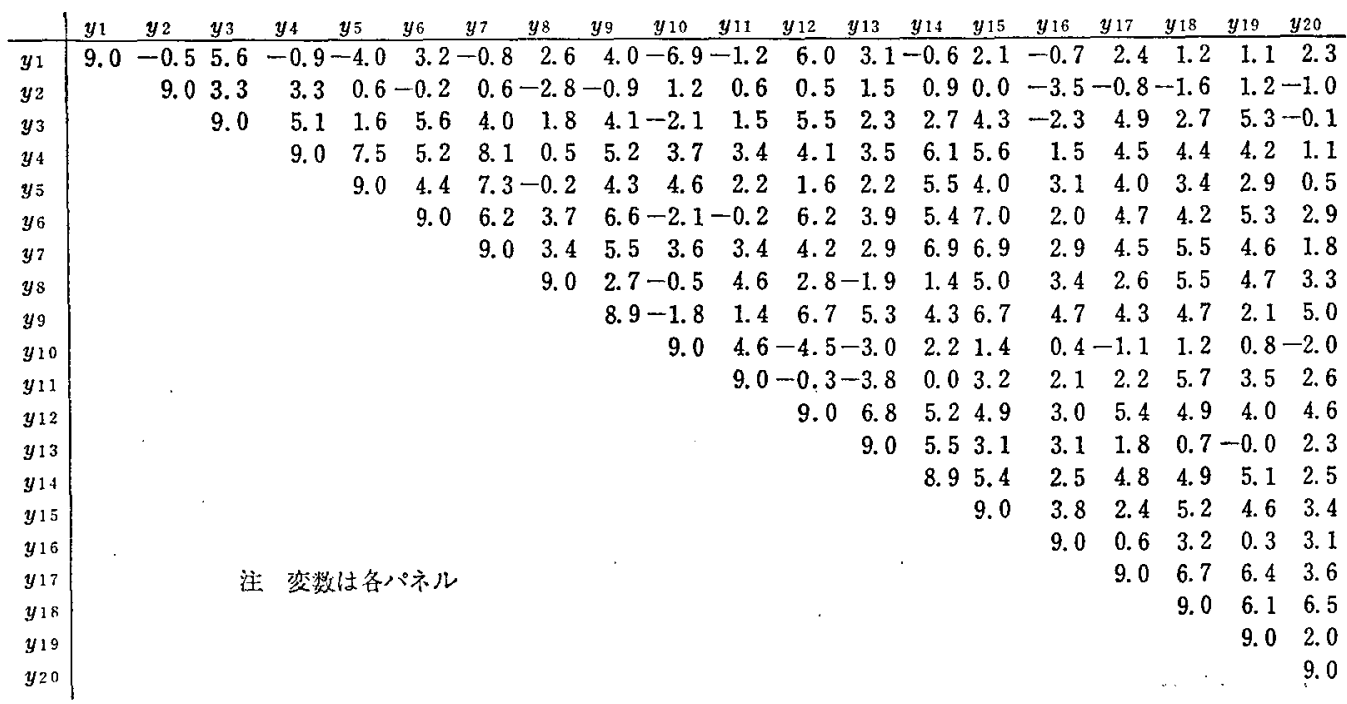


かし，僅か 3パネルであるから，パネルをらたつに分けるというより、データから3パネルを除外する形となる う.一般に，データの一部を解析対象から除く際には十分な検討が必要である.したがって，除外しない方で 解析をすすめるなかで，この3パネルに注目する.

以下，用いた手法について逐次一般的に述べたあと，適用結果を記すことにする．むず，採点の対象となる種 類の数を $p$, 採点を㧍こならパネル数を $n$ とし， $p \times n$ のデータ行列を

$$
\boldsymbol{Y}=\left(\boldsymbol{y}_{1}, \cdots, \boldsymbol{y}_{q}, \cdots, \boldsymbol{y}_{n}\right)
$$

としょう。ただし各 $\boldsymbol{y}_{q}$ は，平均ゼロ，分散は一定であるとする。すると $n$ 变数についての積和行列は

$$
\boldsymbol{S}_{u}=\boldsymbol{Y}^{\prime} \boldsymbol{Y}
$$

と書ける.この行列 $\boldsymbol{S}_{\boldsymbol{y}}$ が，以下の解析の基本となる.

また回帰の把握には，酸を $x_{1}$ ，糖を $x_{2}$ として直交多項式利用を前提とする，以下ここでは，“回㷌項”とは 直交多項式のそれを意味する。

\section{3. 解析方法と適用結果}

\section{1 通常の主成分分析と直交多項式}

$n$ 人のパネルの共通性をひき出すため，先ず考えられるのは $S_{y}$ の主成分分析である. 主成分評点のベクトル を $z$ とすると， $\boldsymbol{z}$ は $\boldsymbol{y}_{1}, \cdots, \boldsymbol{y}_{n}$ の線形結合であるから，その要素の大小と食味の良否とが対応らけられれば，

\begin{tabular}{|c|c|c|c|c|}
\hline \multirow{2}{*}{$\begin{array}{l}\text { 固有へ } \\
\text { 変数 } \\
\text { (パネル) }\end{array}$} & \multicolumn{2}{|c|}{20 変 数 } & \multicolumn{2}{|c|}{17 変 数 } \\
\hline & 第 1 & 第 2 & 第 1 & 第 2 \\
\hline$y_{1}$ & 0.10 & 0.47 & & \\
\hline$y_{2}$ & 0.01 & -0.06 & & \\
\hline$y_{3}$ & 0.22 & 0.15 & 0.21 & -0.06 \\
\hline$y_{4}$ & 0.28 & -0.21 & 0.28 & -0.11 \\
\hline$y_{5}$ & 0.22 & -0.32 & 0.23 & -0.11 \\
\hline$y_{5}$ & 0.29 & 0.11 & 0.29 & -0.13 \\
\hline$y_{7}$ & 0.30 & -0.21 & 0.31 & -0.02 \\
\hline$y_{8}$ & 0.17 & 0.02 & 0.17 & 0.42 \\
\hline$y_{9}$ & 0.29 & 0.14 & 0.29 & -0.14 \\
\hline$y_{10}$ & 0.01 & -0.52 & & \\
\hline$y_{11}$ & 0.12 & -0.28 & 0.13 & 0.51 \\
\hline$y_{12}$ & 0.28 & 0.30 & 0.27 & -0.19 \\
\hline$y_{13}$ & 0.17 & 0.23 & 0.17 & -0.50 \\
\hline$y_{14}$ & 0.27 & -0.10 & 0.27 & -0.19 \\
\hline$y_{15}$ & 0.29 & -0.04 & 0.29 & 0.03 \\
\hline$y_{16}$ & 0.14 & -0.04 & 0.14 & 0.03 \\
\hline$y_{17}$ & 0.25 & 0.04 & 0.25 & 0.08 \\
\hline$y_{18}$ & 0.28 & -0.08 & 0.28 & 0.31 \\
\hline$y_{19}$ & 0.24 & -0.07 & 0.24 & 0.22 \\
\hline$y_{20}$ & 0.18 & 0.12 & 0.18 & 0.15 \\
\hline 固 有 値 & 72.4 & 30.5 & 71.7 & 21.4 \\
\hline 等与率 (\%) & 40.3 & 17.0 & 47.0 & 14. 0 \\
\hline
\end{tabular}

表 3. $S_{y}$ の固有值，固有ベクトル 
表 4. 総合得点とその推定値

\begin{tabular}{|c|rrr|}
\hline ミカン区分 & $z\left(z_{1}\right)$ & \multicolumn{1}{|c|}{$\hat{z}_{(1)}$} & \multicolumn{1}{c|}{$\hat{\mathbf{z}}_{(2)}$} \\
\hline 1 & -0.63 & -1.05 & -0.67 \\
2 & -0.81 & -0.48 & -1.03 \\
3 & -1.82 & -1.81 & -2.19 \\
4 & -4.81 & -5.03 & -4.17 \\
\hdashline 5 & 1.97 & 2.67 & 1.44 \\
6 & -0.38 & -0.01 & 0.93 \\
7 & -1.25 & -1.34 & -0.40 \\
8 & -0.90 & -1.31 & -2.54 \\
\hdashline 9 & 3.49 & 3.13 & 3.99 \\
\hdashline & 4.16 & 3.71 & 3.32 \\
10 & 2.56 & 2.38 & 1.83 \\
11 & -1.56 & -0.88 & -0.47 \\
\hline 12 & & & \\
\hline
\end{tabular}

これを食味の総合得点と考えることができようこことき，固有ベクトルの各要素は，各 $\boldsymbol{y}$ に与える“重み” を意味する。

以下適用結果に沿って述べる.

表 3 に全変数掞よび $y_{1}, y_{2}, y_{10}$ を除いた場合について，第 1 および第 2 固有べクトル，固有值を示す。いずれも 第 1 固有ベクトルの要素は全部正であるから，どのパネルであるらと，高い採点值をるつ対象添と， その主成分 評点の值は高い。しかし $y_{1}, y_{2}$ 括よび $y_{10}$ につては，与充られた重みはかなり小さく，これらは謤点には殆 んど笴与しない，さらに17变数に捺ける第 1 固有べクトルを20变数のそれと比較すると，第 1 主成分はこの 3 パ ネルの有無には殆んど影響されないことが分る．第2 主成分については，固有べトルの要素の値が正負約半数 ずつであり，食味の良否と評点の大小との対応がつかない，以上の結果から，第 1 主成分の評点 $z_{1}$ だけ住，総 合得点として使うことができる． $z_{1}(=z)$ の各値を総合得点として表 4 亿示す．これを見ると，桾は高いほど， 酸は低い注ど, 得点が高い傾向が認められる。

次に直交多項式により回帰を求める， $x_{1}$ について 3 次までの直交多項式を $P_{1 j} ; j=1,2,3 ; x_{2}$ の 1 次扰よび

表 5. 直交多項式の関数值

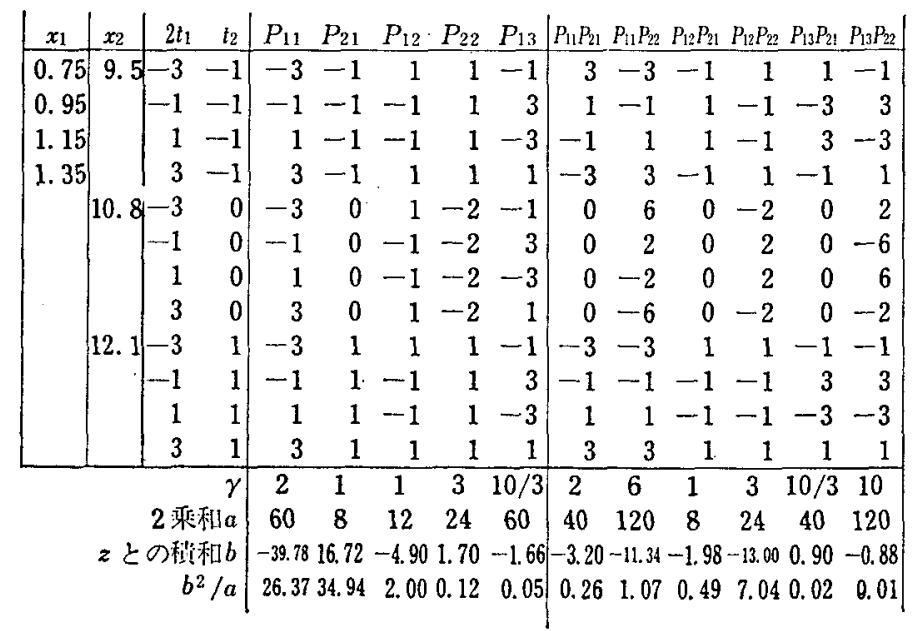


表 6. 第1主成分にふくまれる各回帰項

\begin{tabular}{|c|c|c|c|}
\hline 直交変動因 & 回帰平方和 & 分散 & 回㷌係数 \\
\hline$P_{1}\left(P_{11}\right)$ & 26.37 & 26.37 & -0.663 \\
\hline$P_{2}\left(P_{21}\right)$ & 34.94 & 34.94 & 2.09 \\
\hline$P_{3}\left(P_{12}\right)$ & 2.00 & 2.00 & -0.408 \\
\hline$P_{4}\left(P_{22}\right)$ & 0.12 & 0.12 & \\
\hline$P_{5}\left(P_{13}\right)$ & 0.05 & 0.05 & \\
\hline$P_{6}\left(P_{11} P_{21}\right)$ & 0.26 & & \\
\hline$P_{7}\left(P_{11} P_{22}\right)$ & 1.07 & 1.48 & \\
\hline$P_{8}\left(P_{12} P_{21}\right)$ & 0.49 & & \\
\hline$P_{9}\left(P_{12} P_{22}\right)$ & 7.04 & & -0.542 \\
\hline$P_{10}\left(P_{13} P_{21}\right)$ & 0.02 & & \\
\hline$P_{11}\left(P_{13} P_{22}\right)$ & 0.01 & & \\
\hline 計 & 72.4 & & $(70.4)$ \\
\hline
\end{tabular}

注1）かっこ内の $P_{j k}$ は変数 $x_{j}$ のk次の多項式を示す. $x_{1}$ : 酸; $x_{2}$ : 糖. 以後は簡便に, 左端のような添字 ひとつの略号で示す.

注2）計のかっこ内 70.4 は 4 要図の回帰項の和である.

2 次のそれらを $P_{21}$ および $P_{22}$ とする， $x_{1}$ と $x_{2}$ との積を $P_{11} P_{21}, \cdots, P_{13} P_{22}$ で表わすと， $z^{\prime} z\left(=\lambda_{1}\right)$ はこれら 11 個の直交多項式の平方和比分割される． $x_{1} ， x_{2}$ は表 1 の値をとるから， $t_{1}=\left(x_{1}-1.05\right) / 0.2, t_{2}=\left(x_{2}-10.8\right)$ 1.3 とし， $P_{i j}\left(t_{i}\right)$ の各值が整数になるようにこれらを る.そして表 5 の最下段の上らに各回帰項が計算でき，さらに表6のような回埽係数が得られる。

回帰項の值は，2变数ともに 1 次の項が特沉さい、積の項を加えて誤差項とし，これを用いて検定すると， 1 次の項だけが有意であり，事実，両 1 次項だけで $z^{\prime} z$ の $85 \%$ を占める. 回帰式としては，1次式でかなりの 近似が可能である。しかし糖と酸との交互作用が食味に影響を与兄るといら知見るあるのでそれらを取り入れる ことを考えてみよ5。もし回帰項の大きさを考慮して， $P_{12} P_{22}$ (表6のように略して $P_{9}$ と書く)および $P_{12}\left(P_{3}\right)$ までを取り上げ， $P_{12}=t_{1}{ }^{2}-5 / 4, P_{22}=t_{2}{ }^{2}-2 / 3$ を導入すると，

$$
\begin{aligned}
\hat{z}_{(1)}= & -6.63\left(x_{1}-1.05\right)+16.9\left(x_{1}-1.05\right)^{2}+1.61\left(x_{2}-10.8\right)+1.20\left(x_{2}-10.8\right)^{2} \\
& -24.05\left(x_{1}-1.05\right)^{2}\left(x_{2}-10.8\right)^{2}-0.85
\end{aligned}
$$

を得る。もし回帰項の大きさよりも，結果の式の実用的な利便を考虑して2.次式を用いることにすれば，各 2 次 項と 1 次の積により

$$
\begin{aligned}
\hat{z}_{(2)}= & -6.63\left(x_{1}-1.05\right)-10.2\left(x_{1}-1.05\right)^{2}+1.61\left(x_{2}-10.8\right)+0.13\left(x_{2}-10.8\right)^{2} \\
& -0.62\left(x_{1}-1.05\right)\left(x_{2}-10.8\right)+0.37
\end{aligned}
$$

を得る。これらによる推定值は， $z$ 值とともに表 4 に示した．各糖度別に酸の变化に対する $z$ および $\hat{z}_{(1)}, \hat{z}_{(2)}$ の 値を図 1 に図示してある. $z$ の動きをみると，糖度 10.8 では下に凸，他は上に凸のパタンである.4次式の $\hat{z}_{(1)}$ は当然 $z$ と同じパタンをとるが， $\hat{z}_{(2)}$ は各糖度とも上に凸となる.

式（3），(4）のどちらを克らぶか，は上に述べた $z$ のバタンをどう把党るか，による．2次の積の回帰項の 大ささは全体の10\%であるから，少数のパネルのカク乱によるものもしれない。その判断は保留としたまま， さらに他の角度から情報を引き出すことを考える： $z$ の寄与率は40\%であったから (表 3 参照), 残りの60\%の 部分が，どの上うな回㷌項をもつかをみよう。 


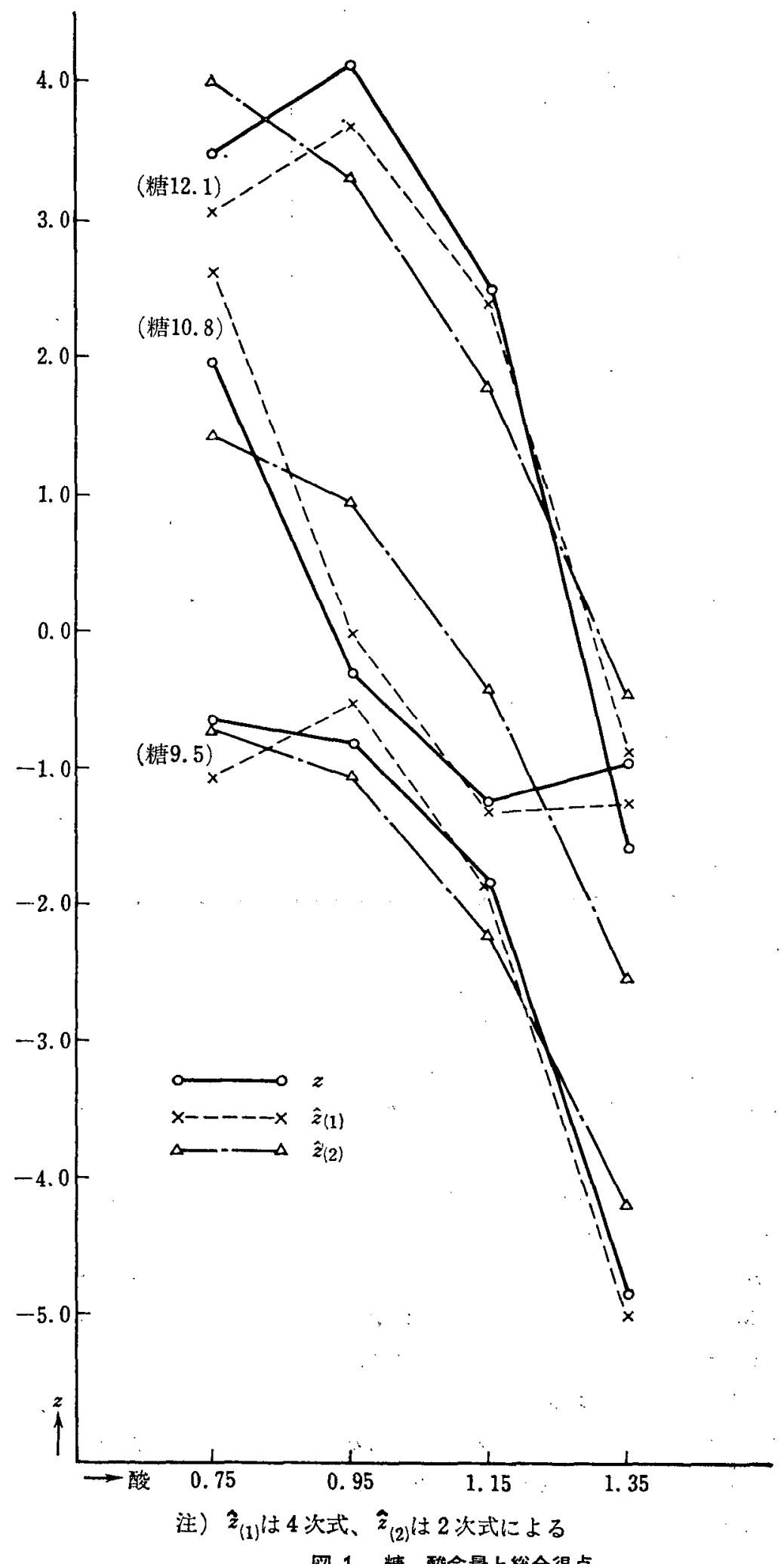

図 1. 糖, 酸合量と総合得点

$$
-116 \text { - }
$$




\section{$3.2 S_{y}$ の固有和の分割}

(1) 手法の概要

$S_{\boldsymbol{v}}$ の固有和を以下のように各回帰項に分割してみる.

一般に対象の数 $p$ に対し，0次を除く之 $p-1$ 個の直交多项式が考之られる， $i$ 番目の多項式の值を， $p$ 要素 から成るベクトル $\boldsymbol{p}_{\boldsymbol{i}}$ で示すと

$$
\boldsymbol{P}=\left(\boldsymbol{p}_{1}, \cdots, \boldsymbol{p}_{i}, \cdots, \boldsymbol{p}_{p-1}\right)
$$

は, $p \times(p-1)$ の行列である. 具体的には表 5 の行列が $\boldsymbol{P}$ に相当する.これらのベクトルで張られる空間の射 影子は

$$
\begin{aligned}
\boldsymbol{P}\left(\boldsymbol{P}^{\prime} \boldsymbol{P}\right)^{-1} \boldsymbol{P}^{\prime} & =\boldsymbol{P}\left(\begin{array}{cc}
\boldsymbol{p}_{1}^{\prime} \underline{p}_{1} & \boldsymbol{O} \\
\varkappa_{\cdots} & \boldsymbol{p}_{p-1}^{\prime} \boldsymbol{p}_{p-1}
\end{array}\right)^{-1} \boldsymbol{P}^{\prime}=\boldsymbol{I}_{p}-\boldsymbol{p}_{p} \boldsymbol{p}_{\mathrm{p}}^{\prime} / \boldsymbol{p}_{p}^{\prime} \boldsymbol{p}_{p} \\
& =\boldsymbol{I}_{p}-\boldsymbol{E}_{1 / p}
\end{aligned}
$$

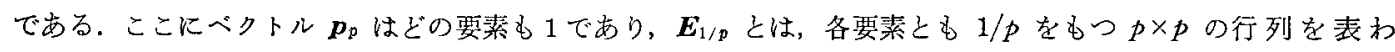
す.すると式（1）におけるべクトル $\boldsymbol{y}_{q}$ は，要絜の和がゼロであるから，

$$
\boldsymbol{Y}^{\prime} \boldsymbol{P}\left(\boldsymbol{P}^{\prime} \boldsymbol{P}\right)^{-1} \boldsymbol{P}^{\prime} \boldsymbol{Y}=\boldsymbol{S}_{v}
$$

と書ける. したがって

$$
\operatorname{tr} \boldsymbol{S}_{y}=\sum_{q} \boldsymbol{y}_{q}^{\prime} \boldsymbol{y}_{q}=\sum_{q} \sum_{i} \boldsymbol{y}_{q}{ }^{\prime} \boldsymbol{p}_{i} \boldsymbol{p}_{i}^{\prime} \boldsymbol{y}_{q} / \boldsymbol{p}_{i}{ }^{\prime} \boldsymbol{p}_{i}
$$

を得るから

$$
\operatorname{tr} \boldsymbol{S}_{\vartheta}=\sum_{i}^{p-1} B_{i}, \quad B_{i}=\sum_{q} \boldsymbol{y}_{q}^{\prime} \boldsymbol{p}_{i} \boldsymbol{p}_{i}^{\prime} \boldsymbol{y}_{q} / \boldsymbol{p}_{i}^{\prime} \boldsymbol{p}_{i}
$$

で， $B_{\imath}$ は，各バネルに和ける $i$ 番目の回㷌項を全パネルについて加えたもの，いわば $\boldsymbol{p}_{i}$ に対する総回帰項で

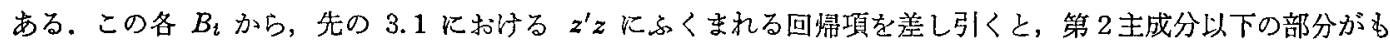

\begin{tabular}{|c|c|c|c|}
\hline 直交変動因 & $\operatorname{tr} S_{\nu} \stackrel{(1)}{\text { の分割 }}$ & $\lambda_{1}$ の分割 & (1)-(2) \\
\hline$P_{1}$ & 39.7 & 26.4 & 13.3 \\
\hline$P_{2}$ & 44.2 & 34.9 & 9.3 \\
\hline$P_{3}$ & 14.3 & 2.0 & 12.3 \\
\hline$P_{4}$ & 10.2 & 0.1 & 10.1 \\
\hline$P_{5}$ & 9.1 & 0.1 & 9.0 \\
\hline$P_{6}$ & 8.6 & 0.3 & 8.3 \\
\hline$P_{7}$ & 10.9 & 1.1 & 9.8 \\
\hline$\therefore \quad P_{8}$ & 7.4 & 0.5 & 6.9 \\
\hline$P_{9}$ & 18.8 & 7.0 & 11.8 \\
\hline$P_{10}$ & 5.6 & 0.0 & 5.6 \\
\hline$P_{1 \mathrm{t}}$ & 10.9 & 0.0 & 10.9 \\
\hline 計 & 179.7 & 72.4 & 107.3 \\
\hline
\end{tabular}
つ回帰項が得られる.

\section{(2) 適用結果}

表 7 の左欄に, 式（9）による各 $B_{\imath}$ の值を示す. ふたつの 1 次項がもっとも大きく, 次汇 2 次項の積 $P_{9}$, そ して $x_{1}$ の 2 次 $P_{3}$ という順序は， $S_{y}$ の第 1 主成分の場合と同じである. $\lambda_{2}$ 以下の部分がるつ回㷌項を表 7 の

表 7. 固有和に心くまれる回帰項 
右欄に示す、これをみると各回帰項の大きさが均一化され，結局第 1 主成分を抽出したあと，みるべき回帰項は 残ってい活い，一方，固有和にふくまれるらたつの 1 次項が占める比率47\%に比べ，第 1 主成分ではそれが85\%

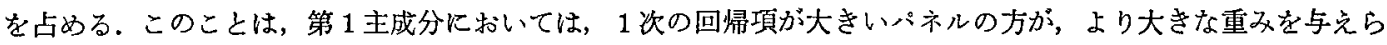
れたことを意味する。そして同時に，たと兊ば $P_{5} ， P_{11}$ など 3 次の回㷌項の大きいパネルの重みは小さかったと 思われる. 2 次の積の項 $\left(P_{9}\right)$ が固有和拉よび第 1 主成分ともに，ほぼ同し比率で抽出されたことをみると，こ の項が少数のパネルの特殊な区応によるとは考えにくい。

\section{3 回帰項を最大にする主成分}

主成分分析とは, 变数の線形結合による分散最大化あるいは無相関への直交変換, といらだけであるから, 第 1 主成分で総合得点として使用できるものが抽出されるとは限らないそこでより明確な目的をもつ主成分を考 えてみよう．回帰項を最大とするような主成分評点を算出し，それを総合得点としてはどらか。すると回州モデ ルを想定しなければならないので，それについての情報が必要である。ここでは 3.1 ， 3.2 に上り得られな情報 を，回帰モデルの想定に利用するが，先ず一般的に手法の概要について述べる.

(1): 手法の概要

行列 $\boldsymbol{S}_{\Downarrow}$ が, 式（7）の左辺のよ5に書けることを利用する. $m$ 個の直交変動因から成るモデルを考光，式 (5)の行列 $\boldsymbol{P}$ から，対応する $m$ 個のベタトルを兄らび，それによる $p \times m$ の行列を $\boldsymbol{P}_{1}$, 残りを $\boldsymbol{P}_{2}$ として

$$
\boldsymbol{P}_{1}=\left(\boldsymbol{p}_{1}, \cdots, \boldsymbol{p}_{m}\right), \boldsymbol{P}_{2}=\left(\boldsymbol{p}_{m+1}, \cdots, \boldsymbol{p}_{p-1}\right)
$$

と畵くことにする.すると

$$
\begin{aligned}
\boldsymbol{P}\left(\boldsymbol{P}^{\prime} \boldsymbol{P}\right)^{-1} \boldsymbol{P}^{\prime} & =\left(\begin{array}{ll}
\boldsymbol{P}_{1} & \left.\boldsymbol{P}_{2}\right)
\end{array}\left(\begin{array}{cc}
\boldsymbol{P}_{1}^{\prime} \boldsymbol{P}_{1} & \boldsymbol{O} \\
\boldsymbol{O} & \boldsymbol{P}_{2}^{\prime} \boldsymbol{P}_{2}
\end{array}\right)^{-1}\left(\begin{array}{c}
\boldsymbol{P}_{1}^{\prime} \\
\boldsymbol{P}_{2}^{\prime}
\end{array}\right)\right. \\
& =\boldsymbol{P}_{1}\left(\boldsymbol{P}_{1}^{\prime} \boldsymbol{P}_{1}\right)^{-1} \boldsymbol{P}_{1}^{\prime}+\boldsymbol{P}_{2}\left(\boldsymbol{P}_{2}^{\prime} \boldsymbol{P}_{2}\right)^{-1} \boldsymbol{P}_{2}^{\prime}
\end{aligned}
$$

であり,したがって

$$
\begin{aligned}
\boldsymbol{S}_{y} & =\boldsymbol{Y}^{\prime} \boldsymbol{P}_{1}\left(\boldsymbol{P}_{1}{ }^{\prime} \boldsymbol{P}_{1}\right)^{-1} \boldsymbol{P}_{1}{ }^{\prime} \boldsymbol{Y}+\boldsymbol{Y}^{\prime} \boldsymbol{P}_{2}\left(\boldsymbol{P}_{2}{ }^{\prime} \boldsymbol{P}_{2}\right)^{-1} \boldsymbol{P}_{2}{ }^{\prime} \boldsymbol{Y} \\
& \equiv \boldsymbol{S}_{y / 1}+\boldsymbol{S}_{y / 2}
\end{aligned}
$$

と， $\boldsymbol{S}_{y}$ の行列を分けることができる．ここで $\boldsymbol{S}_{v / 1}$ は，選択した $m$ 個の变動因だけに関する行列である.こ机 の固有値，固有列べクトルの行列を $\boldsymbol{\Lambda}$ 拉よび $\boldsymbol{L}$ とすると

$$
\begin{aligned}
& \boldsymbol{A}=\boldsymbol{L}^{\prime} \boldsymbol{Y}^{\prime} \boldsymbol{P}_{1}\left(\boldsymbol{P}_{1}^{\prime} \boldsymbol{P}_{1}\right)^{-1} \boldsymbol{P}_{1}^{\prime} Y L \\
& =L^{\prime} \boldsymbol{Y}^{\prime} \boldsymbol{P}_{1}\left(\boldsymbol{P}_{1}^{\prime} \boldsymbol{P}_{1}\right)^{-\frac{1}{2}}\left(\boldsymbol{Y}^{\prime} \boldsymbol{P}_{1}\left(\boldsymbol{P}_{1}^{\prime} \boldsymbol{P}_{1}\right)^{-\frac{1}{2}}\right)^{\prime} \boldsymbol{L}
\end{aligned}
$$

と書ける.したがって

$$
w_{j}^{\prime}=l_{j}^{\prime} Y^{\prime} P_{1}\left(P_{1}{ }^{\prime} P_{1}\right)^{-\frac{1}{2}}
$$

とおき， $\Lambda$ の $j$ 要素を $\lambda_{j}$ とすると， $\boldsymbol{w}_{j}{ }^{\prime} \boldsymbol{w}=\lambda_{j}$ である.すなわち $\boldsymbol{S}_{y / 1}$ の主成分を導出することは, $\boldsymbol{w}$ の分 散の最大化をはかることである。しかし，

$$
z=\boldsymbol{X I}_{3}
$$

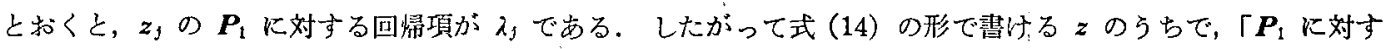

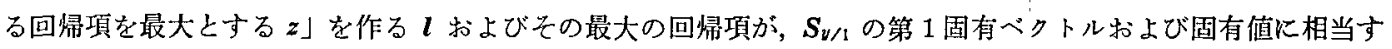
る. さらに

$$
\begin{aligned}
\lambda_{j}=\sum_{i}^{m_{j}} \boldsymbol{z}_{j}^{\prime} \boldsymbol{p}_{i} \boldsymbol{p}_{i}{ }^{\prime} z_{j} / \boldsymbol{p}_{i} \boldsymbol{p}_{i} \\
-118-
\end{aligned}
$$


が成立つから， $\lambda_{j} の$ 值は $m$ 個の回帰項の和である.

上で述べたように， $S_{y / 1}$ の固有値は， $w_{j}^{\prime} w_{j}$ に等しく， $z_{j}^{\prime} z_{j}$ ではない， $z_{j}^{\prime} z_{j}$ は一般に $\lambda_{j}$ よりも大きい，な ぜならば式（11）から

$$
\begin{aligned}
z_{j}{ }^{\prime} z_{j} & =z_{j}{ }^{\prime} \boldsymbol{P}\left(\boldsymbol{P}^{\prime} \boldsymbol{P}\right)^{-1} \boldsymbol{P}^{\prime} z_{j} \\
& =z_{j}{ }^{\prime} \boldsymbol{P}_{1}\left(\boldsymbol{P}_{1}^{\prime} \boldsymbol{P}_{1}\right)^{-1} \boldsymbol{P}_{1}^{\prime} z_{j}+z_{j}{ }^{\prime} \boldsymbol{P}_{2}\left(\boldsymbol{P}_{2}{ }^{\prime} \boldsymbol{P}_{2}\right)^{-1} \boldsymbol{P}_{2}{ }^{\prime} z_{j}
\end{aligned}
$$

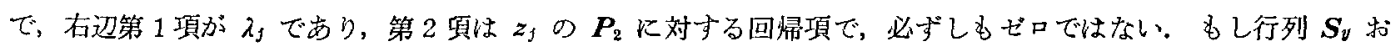
上び $S_{v / 1}$ の最大固有值を $\lambda_{1}{ }^{(1)} ， \lambda_{1}{ }^{(2)}$ と書くことにすると，

$$
\lambda_{1}{ }^{(1)} \geqq z_{1}{ }^{\prime} z_{1} \geqq \lambda_{1}{ }^{(2)}
$$

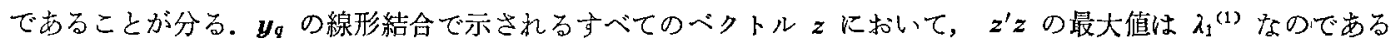
から．逆に $\lambda_{1}{ }^{(2)}$ は， $\boldsymbol{z}$ の $\boldsymbol{P}_{1}$ に対する回帰項の最大值であるから， $\lambda_{1}{ }^{(1)}$ にふくま机る $m$ 個の回帰項の和より 小さくないはずである。以下適用に沿って述べる。

\section{(2) 適用結果と手法に関する若干の考察}

先に計算して表 7 に示した $B_{2}$ の大きさにより $m$ 個のベクトルを兄らび， $\boldsymbol{P}_{1}$ を決めてみよう：

$B_{i}$ の大きさの順にえらべば， $m=2$ では $P_{1}$ と $P_{2}, m=4$ とすると，それに $P_{3}$ と $P_{9}$ を加えることになる.

\begin{tabular}{|c|c|c|c|c|}
\hline \multirow{2}{*}{$\begin{array}{l}\text { 固有べ } \\
\text { 変数 } \\
(\text { パネル } \\
\end{array}$} & \multirow{2}{*}{$\begin{array}{c}S_{y} \\
(m=11)\end{array}$} & \multicolumn{3}{|c|}{$S_{y^{\prime 1}}$ の第 1 主成分 } \\
\hline & & $m=7$ & $m=4$ & $m=2$ \\
\hline$y_{1}$ & 0.10 & 0.10 & 0.10 & 0.10 \\
\hline$y_{2}$ & 0.01 & 0.02 & 0.02 & 0.11 \\
\hline$y_{3}$ & 0.22 & 0,22 & 0.21 & 0.24 \\
\hline$y_{4}$ & 0.28 & 0.28 & 0.29 & 0.32 \\
\hline$y$ & 0.22 & 0.22 & 0.23 & 0.24 \\
\hline$y_{6}$ & 0.29 & 0.30 & 0.30 & 0.28 \\
\hline$y_{7}$ & 0.30 & 0.30 & 0.30 & 0.30 \\
\hline$y_{8}$ & 0.17 & 0.17 & 0. 15 & 0.08 \\
\hline$y_{9}$ & 0.29 & 0.29 & 0.31 & 0.31 \\
\hline$y_{10}$ & 0.01 & 0.01 & 0.01 & -0.01 \\
\hline$y_{11}$ & 0.12 & 0.12 & 0.11 & 0.01 \\
\hline$y_{12}$ & 0.28 & 0.28 & 0.27 & 0.31 \\
\hline$y_{13}$ & 0.17 & 0.17 & 0.19 & 0.25 \\
\hline$y_{14}$ & 0.27 & 0.27 & 0.27 & 0.27 \\
\hline$y_{15}$ & 0.29 & 0.30 & 0.31 & 0.27 \\
\hline$y_{16}$ & 0.14 & 0.16 & 0.16 & 0.14 \\
\hline$y_{17}$ & 0.25 & 0.24 & 0.23 & 0.22 \\
\hline$y_{18}$ & 0.28 & 0.27 & 0.25 & 0.22 \\
\hline$y_{19}$ & 0.24 & 0.24 & 0.21 & 0.19 \\
\hline$y_{20}$ & 0.18 & 0.16 & 0.17 & 0.15 \\
\hline 固有値 $\left(\lambda_{1}{ }^{(2)}\right)$ & 72.4 & 71.6 & 70.7 & 63.7 \\
\hline 表 6 の 和 ${ }^{1}$ & & 71.6 & 70.4 & 61.3 \\
\hline 固 有 和 & 179.7 & 149.0 & 117.0 & 83.9 \\
\hline
\end{tabular}
このようにして， $m=2,4$ 扎よび 7 とたとき，各 $\boldsymbol{S}_{y / 1}$ の最大固有值，固有べクトルを表8に示した，式（17）

表 8. $S_{V / 1}$ の最大固有値, 固有ベクトル

1) ここのそれぞれで用いた直交関数について $\boldsymbol{S}_{\boldsymbol{v}}$ の第 1 固有値のらち回睒項を加えた値. 
衰 9. $m=4$ の $S_{y / 1}, S_{y / 2}$

\begin{tabular}{|c|c|c|c|c|c|c|c|c|c|c|c|c|c|c|c|c|c|c|c|c|}
\hline & & $y_{2}$ & $y 3$ & $y_{4}$ & ys & $y_{6}$ & $y_{7}$ & $y / 8$ & $y 9$ & $y_{10}$ & 11 & $y_{12}$ & $y 1.3$ & $y_{1.4}$ & $y_{15}$ & $y: 6$ & $y_{17}$ & $y: 18$ & $\begin{array}{l}y 19 \\
\end{array}$ & $y_{20}$ \\
\hline 11 & $4.8^{4.3}$ & 1.1 & 2.1 & 0.2 & -1.9 & 1.9 & 0.6 & 3.5 & 3.2 & -2.9 & 1.7 & 3.7 & 1.7 & -0.1 & 2.8 & 1.7 & 0.4 & 2.1 & 0.7 & \\
\hline 12 & & 2.6 .6 & 3.4 & 2.9 & 0.3 & $3-1.2$ & 0.1 & -2.9 & 0.1 & 0.1 & 1.4 & 1. 5 & 1.7 & -0.1 & -1.2 & -2.4 & 0.9 & -0.6 & 0.3 & -0. \\
\hline 13 & 3.4 & $\cdots$ & 3.9. 5.1 & 5.5 & 3.2 & 3.5 & 4.4 & 1.5 & 4.4 & 0.9 & 3.4 & 4. 1 & 2.3 & 3.3 & 4.1 & 0.4 & 3.9 & 3. 8 & 3.7 & \\
\hline & -1.0 & 0.4 & -0.30 & 0.8 .8 & 6.8 & 5.3 & 7.0 & 0.1 & 5. 5 & 2.3 & 2.5 & 4. 9 & 4. 1 & 6.3 & 5.0 & 1.4 & 5.7 & 4.5 & .9 & \\
\hline 15 & -2.1 & 0.3 & -1.6 & 0.7 & $1.7^{7.3}$ & 4.8 & 6.4 & -0.5 & 4.0 & 3.1 & 1.0 & 3. 0 & 3. 2 & 6.2 & 4.0 & 1. 7 & 4.9 & 3.6 & 4.2 & 0. \\
\hline 16 & 1.3 & 1.1 & 2.1 & -0.1 & -0.4 & $2.1^{6.9}$ & 6.4 & 3. 8 & 6.8 & -0.2 & 1.5 & 5.9 & 4. 3 & 5.8 & 6.8 & 4. 4 & 4.5 & 5.4 & 4.3 & 3. \\
\hline 17 & -1.4 & 0.5 & -0.4 & 1.1 & 0.8 & -0.2 & $1.8^{7.2}$ & 2. 2 & 6. 2 . & 1.8 & 2. 3 & 5.0 & 3.7 & 6.5 & 6.3 & 2.9 & 5.5 & $5: 4$ & 0 & \\
\hline 18 & -0.9 & 0.1 & 0.3 & 0.4 & 0.3 & -0.1 & 1. 1 & 2.8 .6 .2 & 4.2 & -1.3 & 2.6 & 2.8 & -0.2 & 1.1 & 5.1 & 2.8 & 1.6 & 4. 1 & 2.3 & \\
\hline 19 & 0.8 & -1.0 & $-0.3-$ & -0.2 & 0.3 & -0.2 & -0.7 & -1.5 & 6.4 & -1.0 & 2.3 & 6.8 & 4.6 & 5.4 & 7.1 & 4.2 & 4.5 & 5.7 & 4. 3 & 4. \\
\hline 110 & -4.1 & 1. 1 & -2.9 & 1.4 & 1.5 & -1.8 & 1. 9 & 0.8 & -0.9 & 4.8 & 1.6 & -2.4 & -2.3 & 1.2 & -0.0 & -2.1 & 1.9 & 0.7 & 1.9 & -2. \\
\hline 111 & -2.9 & -0.8 & -1.9 & 0.9 & 1.2 & -1.7 & 1. 1 & 2.0 & -0.9 & 3.0 & .9 .1 & 1.0 & -1.4 & 0.8 & 3.0 & -0.9 & 2.5 & 3. 1 & .9 & 1. \\
\hline 12 & 2.3 & -1.0 & 1.5 & -0.8 & -1.4 & 0.3 & -0.7 & -0.0 & 01 & 3 & & 1.67 & 6. 0 & 4.7 & 5.7 & 4.2 & 3.4 & 4.3 & 2.9 & 4. \\
\hline 13 & 1.4 & -1.3 & $-0.0-$ & -0.6 & -1.0 & -0.3 & -0.7 & -1.7 & 0.7 & -0.7 & -2.4 & 0.7 & $2.4^{6.6}$ & 4. 3 & 3.1 & 3.7 & 2.1 & 1.9 & 1. 3 & 2. \\
\hline 114 & -0.6 & 1.0 & -0.7 & -0.1 & -0.8 & -0.5 & 0.4 & 0.3 & -1.1 & 1.0 & -0.8 & 0.5 & 1.1 & 2.7 .2 & 5.2 & 3.2 & 4.7 & 4.3 & 4. 0 & 2.0 \\
\hline 115 & -0.7 & 1.2 & 0.2 & 0.6 & -0.0 & 0.2 & 0.6 & -0.2 & -0.4 & 1.5 & 0.2 & -0.8 & 0.0 & 0.3 & $1.5^{7.5}$ & 3.9 & 4.7 & 6.2 & 4. 8 & \\
\hline 116 & -2.4 & -1.1 & -2.8 & 0.0 & 1.3 & -2.4 & -0.1 & 0.6 & 0.5 & 2.4 & 3.0 & -1.3 & -0.6 & -0.7 & -0.1 & 4.7 .3 & 1.4 & 2.6 & 1. 3 & \\
\hline 11 & 2.0 & -1.7 & 0.9 & -1.2 & -0.9 & 0.2 & -1.0 & 1.1 & -0.2 & -3.0 & -0.4 & 2.0 & -0.3 & & -2.3 & & 7 & 4.2 & 4.2 & \\
\hline 118 & -0.9 & -1.1 & -1. & -0.2 & -0.2 & -1.2 & 0.1 & 1.4 & -1.0 & 0.5 & 2.6 & 0.6 & -1.1 & 0.7 & -1.0 & 0.6 & 2.4 & .7 .3 & 4. 3 & 3. \\
\hline 19 & 0.4 & 0.9 & $1.6-$ & -0.7 & -1.3 & 1.0 & -0.4 & 2.3 & -2.2 & -1.1 & 0.6 & 1.1 & -1.3 & 1.0 & $-0.2-$ & -1.0 & 2.3 & 1.8 & $9^{4.1}$ & 2. \\
\hline 120 & -1.3 & -0.5 & $-2.4-$ & -0.5 & 0.2 & -1.0 & -0.9 & -1.0 & 0.3 & 0.0 & 0.9 & 0.2 & -0.0 & 0.6 & -1.2 & 0.1 & 1.8 & 2.9 & & \\
\hline
\end{tabular}

注 右上が斿/1, 左下が $\boldsymbol{S}_{y / 2}$

の大小関係をみることができる． $\lambda_{1}{ }^{(1)}$ のらちの $m$ 個の回帰項を加えた值 $\lambda_{1}{ }^{(2)}$ をこなないことはさきに述べた が,ここでは僅かな差しかない。

$S_{y}$ とは $m=11$ の $S_{y / 1}$ に相当する. 表8によると，これと $m=7$ とでは，固有べクトルは殆えど変らない． これは $m$ を多くとりすぎて， $S_{y / 1}$ の訐算を無意味なるのにした例である. 主成分評点については，どの場合も 総合得点とすることは可能であるが, $m=4$ について計算をすすめてみる.これの $\boldsymbol{S}_{y / 1}$ および $\boldsymbol{S}_{y / 2}$ を表 9 の右 上と左下に示した。このふたつの行列の最大固有值とそれに対応する $z^{\prime} z$ を，式（15）および（16）により回帰 項に分割した結果を表10に示した． $S_{y / 1}$ の $z^{\prime} z$ の回帰項は $\lambda_{1}{ }^{(1)}$ のそれと殆んど变らない。これに上り回非係数 を算出す礼ば式（4）の各俰数と泳添同じなるう。

結果の同異はともかく， $S_{\nu}$ 方るいは $S_{\nu / 1}$ のどちらの主成分を用いるか, はどの解析時点で回㷌モデルを設定

表 10. $S_{y / 1}, S_{y / 2}$ の第1主成分の回帰項

\begin{tabular}{|c|c|c|c|c|c|c|}
\hline \multirow{2}{*}{\multicolumn{2}{|c|}{ 直交変動因 }} & \multirow{2}{*}{$\begin{array}{c}S_{y} \infty \\
\text { 第 } 1 \text { 主成分 }\end{array}$} & \multicolumn{2}{|c|}{$S_{y / 1}$ の第 1 主成分 } & \multicolumn{2}{|c|}{$S_{y / 2}$ の第 1 主成分 } \\
\hline & & & $\lambda$ & $z^{\prime} z$ & $\lambda$ & $z^{\prime} z$ \\
\hline & $P_{1}$ & 26.4 & 26.9 & 26.9 & & 0.62 \\
\hline & $P_{2}$ & 34.9 & 35.2 & 35.2 & & 2.87 \\
\hline & $P_{3}$ & 2.0 & 1. 62 & 1.62 & & 0.28 \\
\hline & $P_{4}$ & 0.1 & & 0.05 & 0.48 & 0.48 \\
\hline & $P_{5}$ & 0.1 & & 0.04 & 5.53 & 5.53 \\
\hline & $P_{6}$ & 0.3 & & 0.19 & 4. 76 & 4. 76 \\
\hline & $P_{7}$ & 1.1 & & 0.74 & 0.60 & 0.60 \\
\hline & $P_{8}$ & 0.5 & & 0.39 & 2.06 & 2.06 \\
\hline & $P_{9}$ & 7.0 & 6.97 & 6.97 & & 0.74 \\
\hline & $P_{10}$ & 0.0 & & 0.02 & 0.90 & 0.90 \\
\hline & $P_{11}$ & 0.0 & & 0.01 & 7.57 & 7.57 \\
\hline & 計 & 72.4 & 70.7 & 72.1 & 21.9 & $26: 4$ \\
\hline & 有 和 & 179.7 & 117.0 & & 62.7 & \\
\hline
\end{tabular}


するか，といら問扎きかえられよう。モデルを想定して総合得点を算出することは，目的が明確である半面制 約も大きい，総合得点とし得るか否かむ，モデルを前提とした上での話となる。モデルの良否についてどこまで 確信をもてるか，は食味と成分の関保についてどの程度の知見があるか，火侬存与る。

この小論における意図は主として手法自身にある，と先に述べた。ひと組のデータに対し，いくつかの解析手 法を適用することは，モデルあるいは解析の態度を変えて検討することになる．通常のデータ解析で，諭議の余 地なしにモデルを設定できるのは，むしろ稀であるといってよく，手法の検討もふくめ，模索しながら解析をす すめ枚ばならない場合の方が多い，しかしそれによって，しばしばデータの構造の把握をより深めることができ る. 次に述べる手法は, 総合得点, 回㷌式といら目的に直接答えられないが, 要因ごとのパネルの採点の動きを みるのは, 必要なことであろう。

\section{4 要因ごとに分解した行列の主成分分析}

$q$ 番目のパネルのデータベクトル $\boldsymbol{y}_{q}$ の構造モデルを

$$
\boldsymbol{y}_{q}=\boldsymbol{u}_{q}+\boldsymbol{v}_{q}+\tilde{\boldsymbol{y}}_{q}
$$

とする， $\boldsymbol{u}_{q} ， \boldsymbol{v}_{q}$ の要素はそれぞれ， $x_{1}$ および $x_{2}$ の各レベルに対し，パネルが（潜在的に）与先た榇点であり

$$
\begin{aligned}
& \boldsymbol{u}_{q}{ }^{\prime}=\left(u_{q 1}, \cdots, u_{q a}, u_{q 1}, \cdots, u_{q a}, \cdots, u_{q 1}, \cdots, u_{q a}\right) \\
& \boldsymbol{v}_{q}{ }^{\prime}=\left(v_{q 1}, \cdots, v_{q 1}, v_{q 2}, \cdots, v_{q 2}, \cdots, v_{q b}, \cdots, v_{q b}\right)
\end{aligned}
$$

\begin{tabular}{|c|c|c|c|c|}
\hline & \multicolumn{2}{|c|}{ 固 有 } & $\eta$ & ル \\
\hline 変数 & $\boldsymbol{S}_{y}$ & $S_{u}$ & $\boldsymbol{S}_{v}$ & $\boldsymbol{S}_{u v}$ \\
\hline$y_{1}$ & 0.10 & -0.11 & 0.27 & -0.22 \\
\hline$y_{2}$ & 0.01 & 0.13 & 0.06 & -0.41 \\
\hline$y_{3}$ & 0.22 & 0.24 & 0.19 & -0.27 \\
\hline$y_{4}$ & 0.28 & 0.42 & 0.15 & 0.02 \\
\hline$y_{5}$ & 0.22 & 0.39 & 0.03 & 0.18 \\
\hline$y_{6}$ & 0.29 & 0.20 & 0.27 & 0.06 \\
\hline$y_{7}$ & 0.30 & 0.34 & 0.17 & 0.24 \\
\hline$y_{8}$ & 0.17 & -0.06 & 0.21 & 0.36 \\
\hline$y_{9}$ & 0.29 & 0.18 & 0.34 & 0.08 \\
\hline$y_{10}$ & 0.01 & 0.24 & -0.21 & 0.24 \\
\hline$y_{11}$ & 0.12 & 0.15 & 0.08 & 0.20 \\
\hline$y_{12}$ & 0.28 & 0.10 & 0.39 & -0.03 \\
\hline$y_{13}$ & 0.17 & 0.09 & 0.27 & -0.09 \\
\hline$y_{14}$ & 0.27 & 0.29 & 0.15 & 0.21 \\
\hline$y_{15}$ & 0.29 & 0.20 & 0.27 & 0.20 \\
\hline$y_{16}$ & 0.14 & -0.01 & 0.22 & 0.37 \\
\hline$y_{17}$ & 0.25 & 0.28 & 0.15 & 0.09 \\
\hline$y_{18}$ & 0.28 & 0.20 & 0.23 & 0.32 \\
\hline$y_{19}$ & 0.24 & 0.25 & 0.13 & 0.12 \\
\hline$y_{20}$ & 0.18 & -0.01 & 0.30 & 0.17 \\
\hline 固有値 & 72.4 & & $\begin{array}{c}44.7 \\
\text { 固有值計 }\end{array}$ & $\begin{array}{r}23.8 \\
109.6\end{array}$ \\
\hline 固 有 和 & 179.7 & 63.1 & 54.4 & 62.2 \\
\hline
\end{tabular}

表 11. 要因ごとの行列の主成分分析 
表 12. 要因別の総合得点

\begin{tabular}{|c|rrr|}
\hline ミカン区分 & \multicolumn{1}{|c}{ 要因 } & \multicolumn{1}{c}{$z_{v}$} & \multicolumn{1}{c|}{$z_{u v}$} \\
\hline 1 & 1.93 & -2.18 & 0.96 \\
2 & 1.42 & -2.18 & -0.61 \\
3 & -0.58 & -2.18 & 0.94 \\
4 & -2.76 & -2.18 & -1.30 \\
\hline 5 & 1.93 & -0.34 & 0.96 \\
6 & 1.42 & -0.34 & -0.67 \\
7 & -0.58 & -0.34 & -2.42 \\
8 & -2.76 & -0.34 & 2.13 \\
\hdashline 9 & 1.93 & 2.52 & -1.93 \\
10 & 1.42 & 2.52 & 1.28 \\
11 & -0.58 & 2.52 & 1.47 \\
12 & -2.76 & 2.52 & -0.83 \\
\hline & & & \\
\hline
\end{tabular}

と書ける. $a$ は $x_{1}$ のレベルの数, $b$ は $x_{2}$ のそれで, $a b=p$ である. $\tilde{y}_{a}$ は交互作用のベクトルを示す. 式 (18) 3.5

$$
\begin{aligned}
\boldsymbol{S}_{\nu} & =\left(\boldsymbol{y}_{q}^{\prime} \boldsymbol{y}_{r}\right)=\left(\boldsymbol{u}_{q}^{\prime} \boldsymbol{u}_{r}\right)+\left(\boldsymbol{v}_{q}^{\prime} \boldsymbol{v}_{r}\right)+\left(\tilde{\boldsymbol{y}}_{q}^{\prime} \tilde{\boldsymbol{y}}_{\tau}\right) \\
& =\boldsymbol{S}_{u}+\boldsymbol{S}_{v}+\boldsymbol{S}_{u v}
\end{aligned}
$$

と， $S_{v}$ を分解できる。このそれぞれから主成分を導出すると，要因ごとの主成分が得られる.

適用結果を表 11〜13に示す. 各行列の最大固有値と固有べクトルは表 11 にある. 左端に示した $\boldsymbol{S}_{\boldsymbol{y}}$ の固有べ クトルと比較すると，特に $y_{1} ， y_{2}$ および $y_{10}$ につて興味深い， $y_{1}$ は酸拉よび交互作用についての好みが， 他の多数と異なるが，糖については大勢と同じ好みをもつ， $y_{10}$ は糖だけについて， $y_{2}$ は交互作用だけについ て，一般の好みと逆である。したがって，一般との共通性を殆んどもたないと思われるパネルも，特定の要因に ついては必ずしもそうでないことが分る。

表 11 をると，各行列の固有和は $\boldsymbol{S}_{v}$ のそれが少ないが，最大固有值はもっとも大きい，糖分に対する好み の方向が一致し易く，共通部分がより大きいことを示す，要因別の総合得点（行列の添字と対応させて $z_{u}, z_{v}$ および $z_{u v}$ と書く）を表 12 に示したが，これらの 2 乗和にふくまれる各回帰項の大きさを表 13 亿記す。 $z_{u}$

表 13. 要因別行列の第 1 主成分の回帰項

\begin{tabular}{|c|ccc|}
\hline 直交変動因 & $S_{u}$ & $S_{v}$ & $S_{u v}$ \\
\hline$P_{1}$ & 38.8 & & \\
$P_{2}$ & & 44.1 & \\
$P_{3}$ & 2.1 & & \\
$P_{4}$ & & 0.7 & \\
$P_{5}$ & 0.3 & & \\
$P_{6}$ & & & 1.9 \\
$P_{7}$ & & & 0.2 \\
$P_{8}$ & & & 2.9 \\
$P_{9}$ & & & 14.3 \\
$P_{10}$ & & & 1.4 \\
$P_{11}$ & & & 3.1 \\
\hline 計 & 41.1 & 44.7 & 23.8 \\
\hline
\end{tabular}


$z_{v}$ においては，今までと同様汇 1 次項が大きい，

$\boldsymbol{S}_{u v}$ の固有ベクトルは，負の要素がいくつかあり，特に $y_{1}$ 〜 y 3 のパネルが他と異なる.しかし全体としては $z_{u v}$ の值の大きさが食味の良さを示すと考えてよいであるう．そしてそれの回帰項の大半は 2 次の積が占め，交 互作用のうちでは，この項を無視できないことを示す。

\section{4. 結 び}

先ず手法についてふれておきたい。ここで用いた手法はいずれも，理論的にさして目新しいものではない。固 有和の分割は，単に回带項の和を求めたるのである．回州を最大にする主成分，とここで名づけた手法は，正準 相関分析の特殊形といえる。まぎらわしいが，奥野ら（1971）火よる“回㷌主成分分析”よりはをしろ“補助変 数之独立な主成分分析”放るいは “外的基準が間隔尺度の場合の主成分分析”（柳井・高根による）と考学を一

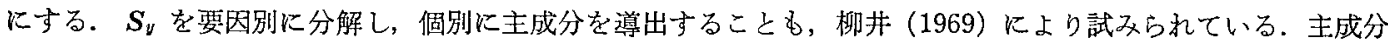
分析については多くの適用事例がみられるが，それの応用，变形についてもさらに適用例が蓄積されることが望 まれる。

值交多項式の算出に用いられる直交関数のベクトルは，その性質上利用価値が高いたと充ば，行列 $\boldsymbol{P}$ を各 成分拉よび交互作用に対応する 3 つ行列に分け，その射影子を用いることにより，行列積の操作だけで $S_{u} な$ どが求められることを指摘しておきたい，直交するべクトルから成る行列は扱いやすく，便利な特質を多くもつ から，構造的な多変量データの解析には，多くの利用法があると思われる.

ここでの解析においては，第 1 主成分の評点を総合得点とすることができた，常にそれが可能であるとは限ら ないので，異なる接近法が必要な場合もあるう．先ずパネルを分類することも考えられる．末た，総合得点とし てょいか否がついても，より明確な判断基準定要することもあるう。これまで特に述べなかったがここでは 固有ベクトルの要素の負（正）符号の数が 5 個までならばその主成分評点を総合得点とし得ると考えた。この基 準は符号検定の $n=20$ の両側 $5 \%$ 有意点による. 3.4 と打ける $z_{u v}$ の大きと食味の良さと対応づけたのは， この基準による，もしこの対応づけが不可能であれば，食咊に対する 2 次の積の影響を指摘できない。

最後に，式（3）と（4）のどちらをえらぶか，の結論は（3）として执きたい，このデータで2次の積を無 視しょうとするのであれば、むしろ1次式のままでよいであるう。いうまであなくこの結論を絶対視するもので はなく，式（4）に実用上の利点が多いことも事実である.しかしここでは，3.1〜3.4の解析結果に沿って結論 つけるしかない。

最後に，貴重な助言をいただいたレフェリーの方々に謝意を表したい。

\section{参 考 文 献}

[1] C.R. Rao (1964): The use and interpretation of principal component analysis in applied research SANKHYA, Vol. 26.

〔2] 楖井晴夫（1969）：職業適正検查の因子分析，教有心理学研究，第17巻第 1 号.

[3] 奥野忠一他 (1971)：多変量解析法，日科技連.

〔4]鉿木晴夫・石田隆（1976）：「温州ミカンの食味と果実中の糖, 酸含量との関俰について」静岡柑梸試 験埸報告第13号.

[5]柳井啨夫・高根䓅雄 (1977)：多变量解析法, 朝會書店. 